\title{
Fusarium graminearum Species Complex Associated with Maize Crowns and Roots in the KwaZulu-Natal Province of South Africa
}

S. C. Lamprecht and Y. T. Tewoldemedhin, Agricultural Research Council-Plant Protection Research Institute, Stellenbosch 7599, South Africa; W. J. Botha, Agricultural Research Council-Plant Protection Research Institute, and F. J. Calitz, Agricultural Research Council-Biometry Unit, Pretoria 0001, South Africa

\begin{abstract}
Lamprecht, S. C., Tewoldemedhin, Y. T., Botha, W. J., and Calitz, F. J. 2011. Fusarium graminearum species complex associated with maize crowns and roots in the KwaZulu-Natal province of South Africa. Plant Dis. 95:1153-1158.

Thirty-three isolates of the Fusarium graminearum species complex obtained from diseased maize (Zea mays) crowns and roots in the Winterton district, KwaZulu-Natal province of South Africa were identified to species level. Their pathogenicity and virulence to maize 'PHI 32D96B' seedlings were determined under glasshouse conditions, with seedling survival and growth and crown and root rot as criteria. Phylogenetic analyses using the 3-O-acetyltransferase (Tri101) gene region sequences revealed the presence of $F$. boothii (2 isolates), $F$. graminearum sensu stricto (26 isolates), and $F$. meridionale (5 isolates) in the $F$. graminearum species complex associated with diseased maize crowns

and roots. Pathogenicity results showed that $F$. boothii was the most and $F$. meridionale the least virulent of the three species. F. boothii and $F$. graminearum sensu stricto significantly reduced survival of seedlings and all three species caused significant reduction in growth and significantly more crown and root rot than the control (uninoculated). This is the first report of $F$. boothii, F. graminearum sensu stricto, and $F$. meridionale associated with diseased maize crowns and roots and their pathogenicity and virulence as soilborne pathogens on maize seedlings in South Africa.
\end{abstract}

Fusarium graminearum (Schwabe) is a well-known cob and stalk rot pathogen of maize (Zea mays L.) $(27,33)$. The fungus is also an important scab pathogen of wheat, particularly where maize and wheat are planted in rotation (28). On maize, $F$. graminearum has been recorded to cause seedling blight and root rot $(7,19,20)$. Asran and Buchenhauer (2) and Moreno-González et al. (19) regarded $F$. graminearum to be an important root rot pathogen of maize. Similarly, Miller (18) considered F. graminearum of prime importance as a soilborne pathogen of maize but Hornby and Ullstrup (9) only occasionally isolated $F$. graminearum from maize roots. In a study on lodging of maize plants, Andrés Ares et al. (1) isolated $F$. semitectum, $F$. graminearum, $F$. culmorum, $F$. solani, and $F$. verticillioides from lodged plants. In pathogenicity tests, they found that $F$. graminearum was the most virulent fungus considering either root rot or seedling growth reduction. The importance of $F$. graminearum as a root rot pathogen is also highlighted by studies on resistance of maize genotypes to seedling blight or root rot and root lodging by several researchers $(2,7,19)$.

In South Africa, F. graminearum causes cob and stalk rot of maize and also scab of wheat $(16,17)$. The fungus was previously isolated from maize roots in South Africa by Chambers $(3,4)$. Testing seven isolates of the fungus, he found that the fungus did not cause significant reduction in seedling emergence. Although he evaluated the capacity of the fungus to infect roots, he did not record the severity of root rot incited by the pathogen. In field trials conducted on no-till maize in the KwaZulu-Natal province since 2005, Lamprecht et al. (14) frequently isolated $F$. graminearum (based on morphological identification according to Nelson et al. [21]) from maize plants displaying crown and root rot. The incidence of the fungus also significantly increased on crowns and roots toward the end of the growing season (14). Ramsey (25) also

Corresponding author: S. C. Lamprecht, E-mail: lamprechts@arc.agric.za

Accepted for publication 30 April 2011.

doi:10.1094/PDIS-02-11-0083

(C) 2011 The American Phytopathological Society found higher incidences of $F$. graminearum in maize roots and stalks at harvest than earlier in the season.

The $F$. graminearum species complex currently consists of 13 described and 1 undescribed phylogenetic species- $F$. acaciaemearnsii, F. aethiopicum, $F$. asiaticum, F. austroamericanum, $F$. boothii, F. brasilicum, F. cortaderiae, F. gerlachii, F. graminearum, F. meridionale, F. mesoamericanum, Fusarium sp., F. ussurianum, and $F$. vorosii $(23,31,34)$ - of which $F$. asiaticum (= lineage 6$), F$. austroamericanum (= lineage 1$), F$. boothii (= lineage 3$), F$. meridionale $(=$ lineage 2$)$, and $F$. graminearum (= lineage 7 ) have been recorded on maize (22). Isolates from maize in South Africa have been identified as $F$. boothii (22). None of the newly described species have been recorded from maize crowns and roots and their importance as soilborne pathogens has not been determined. The aim of this study was to determine the species within the $F$. graminearum species complex that are associated with maize crowns and roots in the trial in KwaZulu-Natal province in South Africa and to determine their pathogenicity and virulence toward maize seedlings.

\section{Materials and Methods}

Isolates. Isolates used in this study were obtained mostly from maize roots collected in the Winterton district, KwaZulu-Natal province, South Africa and are listed in Table 1.

Identification of $\boldsymbol{F}$. graminearum species complex isolates to the species level. DNA extractions were conducted from $F$. graminearum species complex cultures. DNA was extracted from 5-day-old Fusarium cultures growing on potato dextrose agar medium (Biolab Diagnostics, Midrand, South Africa). Fungal mycelia were transferred to a $2.2 \mathrm{ml}$ centrifuge tube containing $1 \mathrm{ml}$ of sodium dodecyl sulfate extraction buffer (15) and $0.5 \mathrm{~g}$ of glass beads. Mycelia were lysed by shaking the tubes for $5 \mathrm{~min}$ in a mixer/miller (Retsch MM301, GmbH \& Co., Haan, Germany) at maximum speed. DNA was isolated from the lysed cells as described by Lee and Taylor (15). DNA integrity was checked by running DNA samples on $1.0 \%$ agarose gels followed by ethidium bromide staining. DNA was visualized and photographed under UV illumination. DNA quantification was conducted using a NanoDrop Spectrophotometer (NanoDrop Technologies, Wilmington, $\mathrm{DE})$. 
Polymerase chain reaction (PCR) amplification and sequencing of the 3-O-acetyltransferase (Tri101) gene were conducted. A region of the Tri101 gene was PCR amplified from South African $F$. graminearum species complex isolates $(n=33)$ using the primer pair AT1 and AT2 (11). Reactions were carried out in a total volume of $40 \mu \mathrm{l}$ that included $5 \mu \mathrm{l}$ of diluted DNA ( 5 to $10 \mathrm{ng}$ ), 0.65 units of BIOTAQ DNA polymerase (Bioline, USA Inc., Taunton, MA), $1 \times$ PCR buffer (Bioline, USA Inc.), $0.2 \mathrm{mg}$ of bovine serum albumin Fraction V (Roche Diagnostics, Randburg, South Africa), $2 \mathrm{mM} \mathrm{MgCl} 2,200 \mu \mathrm{M}$ each $\mathrm{dNTP}$, and $0.2 \mu \mathrm{M}$ of each primer. Amplification reactions were conducted in a 2700 thermal cycler (Applied Biosystems, Foster City, CA) using amplification conditions consisting of an initial denaturation at $95^{\circ} \mathrm{C}$ for $5 \mathrm{~min}$; followed by 45 cycles of $95^{\circ} \mathrm{C}$ for $30 \mathrm{~s}, 55^{\circ} \mathrm{C}$ for $30 \mathrm{~s}$, and $72^{\circ} \mathrm{C}$ for 2 min; with a final extension step at $72^{\circ} \mathrm{C}$ for $10 \mathrm{~min}$. Resulting PCR products $(5-\mu$ l aliquot) were run and visualized as described above for genomic DNA.

PCR products were purified using an MSB Spin PCRapace (Invitek, Berlin) kit according to manufacturer's instructions. PCR products were sequenced using primers AT1 or AT2 and the BigDye master mix reaction mix (version 3.1 dye terminators; Applied Biosystems), according to the manufacturer's instructions. Sequence reaction products were run by the Central Analytical Sequencing Facility at Stellenbosch University using an ABI 3130XL Genetic Analyzer. Geneious Pro 3.6.2 (Biomatters Ltd., Auckland, New Zealand) was used to view ABI trace files and to obtain consensus double-strand sequences for each isolate.

Phylogenetic analyses of the Tri101 gene sequence data. The $F$. graminearum species complex sequences $(n=33)$ were aligned in Geneious Pro. Fourteen reference sequences representing all known B-trichothecene clade species were included from the studies of O'Donnell et al. (23), Starkey et al. (31), and Yli-Mattila et al. (34). F. pseudograminearum and Fusarium sp. (NRRL29380 and NRRL29298) sequences were used as outgroups.

Sequences were aligned online using the software MAFFT alignment program, version 6 (10). Alignments were adjusted manually using the software Geneious Pro 3.6.2 (Biomatters Ltd.). Maximum parsimony analysis was conducted in Phylogenetic Analysis Using Parsimony (PAUP) $4.0 \mathrm{~b} 10$ (32). Maximum parsimony analysis was performed using the heuristic search option with 100 random taxon additions. Tree bisection and reconstruction was used as the branch swapping algorithm, with the option of saving no more than 10 trees with a score greater than or equal to 5 (8). Gaps were treated as missing data. All characters were unordered and of equal weight. Bootstrap support values were calculated from 1,000 heuristic search replicates and 100 random taxon additions. Other measures calculated for parsimony included tree length, consistency index, retention index, and the rescaled consistency index values.

Pathogenicity tests. Sand-bran inoculum was prepared according to Lamprecht (13). Autoclaving times were adapted to $60 \mathrm{~min}$ on the first day followed by $30 \mathrm{~min}$ on two consecutive days. Ten plugs ( $2 \mathrm{~mm}$ in diameter) of each isolate, grown on water agar (WA) medium (Agar Bacteriological; Biolab Diagnostics) at $22^{\circ} \mathrm{C}$ for 14 days, were used to inoculate two 1-liter flasks. Control flasks only contained plugs of WA. The inoculum was incubated for 11 days at $22^{\circ} \mathrm{C}$ without being directly exposed to light. The mixture was shaken every fourth day to ensure even growth of the mycelium throughout the medium.

The pathogenicity trial was conducted in a glasshouse $\left(18^{\circ} \mathrm{C}\right.$ night and $28^{\circ} \mathrm{C}$ day temperatures) using plastic pots, $22.5 \mathrm{~cm}$ in diameter, with a holding capacity of $1,500 \mathrm{~g}$ of planting medium. The planting medium was made up of equal amounts of soil, perlite and sand, which was pasteurized $\left(30 \mathrm{~min}\right.$ at $\left.83^{\circ} \mathrm{C}\right)$ and left for

Table 1. Strain details and GenBank accession numbers of Fusarium isolates obtained from maize in the Winterton District of KwaZulu-Natal, South Africa and GenBank accessions for the 3-O-acetyltransferase gene sequences

\begin{tabular}{|c|c|c|c|c|}
\hline Species & Accession number ${ }^{x}$ & Previous crop ${ }^{y}$ & Plant part & GenBank accession $^{z}$ \\
\hline \multirow[t]{5}{*}{$\overline{\text { Fusarium meridionale }}$} & PPRI 10696 & Wheat & Root & HQ909103 \\
\hline & PPRI 10698 & Wheat & Root & HQ909104 \\
\hline & PPRI 10704 & Wheat & Root & HQ909105 \\
\hline & PPRI 10706 & Wheat & Root & HQ909106 \\
\hline & PPRI 10710 & Wheat & Crown & HQ909107 \\
\hline \multirow[t]{2}{*}{ F. boothii } & PPRI 10703 & Wheat & Root & HQ909108 \\
\hline & PPRI 10724 & Wheat & Root & HQ909109 \\
\hline \multirow[t]{26}{*}{ F. graminearum sensu stricto } & PPRI 10693 & Wheat & Root & HQ909110 \\
\hline & PPRI 10694 & Wheat & Root & HQ909111 \\
\hline & PPRI 10695 & Wheat & Root & HQ909112 \\
\hline & PPRI 10697 & Wheat & Root & HQ909113 \\
\hline & PPRI 10699 & Wheat & Root & HQ909114 \\
\hline & PPRI 10700 & Wheat & Root & HQ909115 \\
\hline & PPRI 10701 & Wheat & Root & HQ909116 \\
\hline & PPRI 10702 & Wheat & Root & HQ909117 \\
\hline & PPRI 10705 & Wheat & Root & HQ909118 \\
\hline & PPRI 10707 & Wheat & Root & HQ909119 \\
\hline & PPRI 10708 & Wheat & Root & HQ909120 \\
\hline & PPRI 10709 & Wheat & Crown & HQ909121 \\
\hline & PPRI 10711 & Wheat & Crown & HQ909122 \\
\hline & PPRI 10712 & Wheat & Root & HQ909123 \\
\hline & PPRI 10713 & Wheat & Root & HQ909124 \\
\hline & PPRI 10714 & Wheat & Root & HQ909125 \\
\hline & PPRI 10715 & Wheat & Root & HQ909126 \\
\hline & PPRI 10716 & Wheat & Root & HQ909127 \\
\hline & PPRI 10717 & Wheat & Crown & HQ909128 \\
\hline & PPRI 10718 & Black oat & Crown & HQ909129 \\
\hline & PPRI 10719 & Black oat & Root & HQ909130 \\
\hline & PPRI 10720 & Wheat & Root & HQ909131 \\
\hline & PPRI 10721 & Wheat & Root & HQ909132 \\
\hline & PPRI 10722 & Crambe & Root & HQ909133 \\
\hline & PPRI 10723 & Canola & Crown & HQ909134 \\
\hline & PPRI 10725 & Wheat & Root & HQ909135 \\
\hline
\end{tabular}

${ }^{x}$ Cultures deposited in the National Collection of Fungi at ARC-Plant Protection Research Institute in Pretoria, South Africa.

y Crops that preceded maize in rotation system trial.

${ }^{z}$ GenBank accession numbers of Fusarium isolates for which sequences were generated and submitted in this study. 
3 days before being mixed with inoculum. An inoculum concentration of $0.5 \%$ sand-bran inoculum/planting medium (wet wt/wet wt) was used. The inoculum was mixed with the planting medium and pots were watered and left to stand overnight in the glasshouse before being planted with 10 maize seeds ('PHI 32D96B') the next day. Maize seed were treated with hot water at $60^{\circ} \mathrm{C}$ for $5 \mathrm{~min}(5)$ to ensure that clean seed was used. Pots were watered every alternate day to field capacity. Pathogenicity and relative virulence of each isolate were determined by calculating the percentage survival and plant growth (shoot length) as well as the percentage of plants with crown and root rot severity using a 0 -to- 4 scale, with $0=$ no root rot, $1=>0$ to $25 \%$ root rot, $2=>25$ to $50 \%$ root rot, $3=>50$ to $75 \%$ root rot, and $4=>75$ to $100 \%$ root rot, 3 weeks after planting. To confirm the presence of the different fungi, reisolations were made by plating, on potato dextrose agar, 5-mm pieces of tissue excised from crowns and roots of plants with crown and root rot representatively selected from each treatment. The experimental design was a randomized complete block design with three block replicates for each treatment ( 33 isolates plus a control), and the trial was repeated.

Statistical analysis. Data were subjected to an appropriate analysis of variance using SAS statistical software (version 9.2;

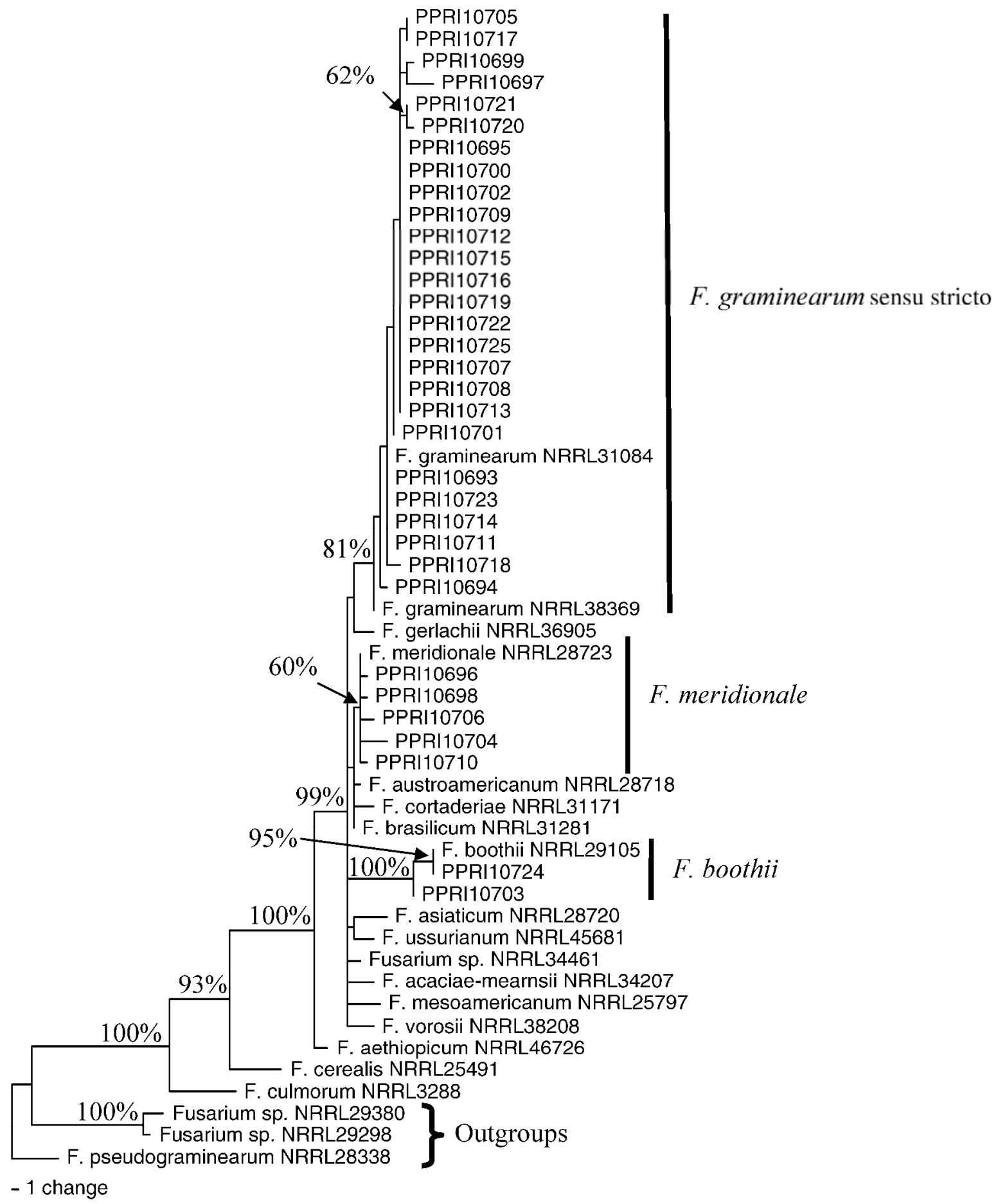

Fig. 1. Phylogeny of Fusarium graminearum species complex based on the 3-0-acetyltransferase (Tri101) gene region. The tree presents one of 244 most parsimonious trees obtained from a heuristic search. Numbers within the tree represent the bootstrap values, with values lower than $60 \%$ not shown. Length $=174$, consistency index $=$ 0.868 , retention index $=0.929$, and rescaled consistency index $=0.806$. F. graminearum species complex isolates obtained from South African maize crowns and roots are indicated with "PPRI" codes. The remaining isolates are from the studies of Starkey et al. (31), O'Donnell et al. (23), and Yli-Mattila et al. (34). F. pseudograminearum and two Fusarium spp. were used as outgroups. 
SAS Institute, Inc., Cary, NC) and the standardized residuals were tested for deviation from normality using Shapiro-Wilk's test (30). The Student's protected least significant difference $t$ tests were calculated at the 5\% significance level to compare means for significant effects.

\section{Results}

Identification of $\boldsymbol{F}$. graminearum species complex isolates to the species level. The alignment of the Tril01 gene sequences contained 1,336 characteristics, of which 88 were parsimony informative, 61 were variable and parsimony uninformative, and 1,187 were constant. The Tril01 phylogeny showed that the South African isolates obtained from maize clustered into three well-supported clades (63 to $100 \%$ bootstrap) representing $F$. graminearum sensu stricto, F. meridionale, and $F$. boothii (Fig. 1). Within the $F$. boothii clade, one South African maize isolate is a genetically divergent strain (PPRI 10703). Therefore, these three species were considered to be the only species currently known to be associated with maize crowns and roots in South Africa (Fig. 1).

Pathogenicity. Survival of maize seedlings was significantly $(P$ $\leq 0.05$ ) reduced for maize planted in soil infested with $F$. boothii and $F$. graminearum sensu stricto (Table 2 ). In trial 2, the two isolates of $F$. boothii were significantly more virulent than the isolates representing the other species but, in trial 1 there was no significant difference between the two Fusarium spp. with regard to their effect on survival of maize seedlings (Table 2). In addition, both species caused a reduction in growth of maize seedlings
(Table 2). Similar to the survival data, F. boothii also caused significantly more reduction in growth than the other two species in trial 2 (Table 2; Fig. 2A). In trial 1, there was no significant difference in the growth reduction reported for $F$. boothii and $F$. graminearum sensu stricto (Table 2 ).

All three species significantly $(P \leq 0.05)$ increased the percent plants with crown rot and also root rot severity compared with the control (Table 2). Crown rot results for the two trials were similar, with maize seedlings grown in soil infested with $F$. boothii having significantly higher percentages of crown rot compared with seedlings grown in soil infested with $F$. graminearum sensu stricto and $F$. meridionale (Table 2). F. graminearum sensu stricto and $F$. meridionale also did not differ significantly in their ability to cause crown rot. Root rot severity of maize seedlings in soil infested with $F$. boothii (Fig. 2B) was also significantly higher than in soil infested with $F$. graminearum sensu stricto and $F$. meridionale (Table 2). In trial 1 , inoculation with $F$. graminearum sensu stricto resulted in significantly higher root rot severities than those recorded for $F$. meridionale but there was no significant difference in root rot severity recorded for the two species in trial 2 (Table 2).

Isolates of $F$ graminearum sensu stricto but not $F$. boothii and $F$. meridionale differed significantly in their ability to reduce survival (Table 3 ) and isolates of $F$. graminearum sensu stricto and $F$. meridionale but not $F$. boothii differed significantly in their ability to cause crown rot (Table 4). Isolates of all three species differed significantly in their ability to cause root rot (Table 4) and reduce

Table 2. Effect of Fusarium boothii, F. graminearum sensu stricto, and F. meridionale on survival, growth, and crown and root rot of maize seedlings ${ }^{\mathrm{x}}$

\begin{tabular}{|c|c|c|c|c|c|c|c|c|}
\hline \multirow[b]{2}{*}{ Fusarium spp. } & \multicolumn{2}{|c|}{ Survival (\%) } & \multicolumn{2}{|c|}{ Shoot length(mm) } & \multicolumn{2}{|c|}{ Crown $\operatorname{rot}(\%)^{y}$} & \multicolumn{2}{|c|}{ Root rot severity ${ }^{z}$} \\
\hline & Trial 1 & Trial 2 & Trial 1 & Trial 2 & Trial 1 & Trial 2 & Trial 1 & Trial 2 \\
\hline Control & $97 \mathrm{a}$ & $100 \mathrm{a}$ & $327 \mathrm{a}$ & $490 \mathrm{a}$ & $0 \mathrm{c}$ & $0 \mathrm{c}$ & $0.0 \mathrm{~d}$ & $0.0 \mathrm{c}$ \\
\hline F. boothii & $68 \mathrm{c}$ & $43 c$ & $224 c$ & $310 \mathrm{c}$ & $89 a$ & $89 a$ & $3.1 \mathrm{a}$ & $2.3 \mathrm{a}$ \\
\hline F. graminearum & $78 \mathrm{bc}$ & $64 \mathrm{~b}$ & $224 c$ & $415 \mathrm{~b}$ & $69 \mathrm{~b}$ & $69 \mathrm{~b}$ & $2.6 \mathrm{~b}$ & $1.2 \mathrm{~b}$ \\
\hline F. meridionale & $95 \mathrm{ab}$ & $91 \mathrm{a}$ & $258 \mathrm{~b}$ & $441 \mathrm{~b}$ & $54 \mathrm{~b}$ & $54 \mathrm{~b}$ & $1.7 \mathrm{c}$ & $1.0 \mathrm{~b}$ \\
\hline
\end{tabular}

${ }^{x}$ A randomized block design with three replicates was used for each trial. Maize seed were planted in pasteurized planting medium (equal amounts of soil, sand, and perlite) artificially inoculated with sand-bran inoculum of $F$. boothii, F. graminearum sensu stricto, and F. meridionale. Percent survival and plant growth (shoot length) as well as percent plants with crown and root rot severity were recorded 3 weeks after planting (inoculation). Means in a column followed by the same letter do not different significantly $(P=0.05)$

${ }^{\mathrm{y}}$ Crown rot $=$ percent plants with crown rot.

${ }^{\mathrm{z}}$ Root rot severity scale: $0=$ no root rot, $1=>0$ to $25 \%$ root rot, $2=>25$ to $50 \%$ root rot, $3=>50$ to $75 \%$ root rot, and $4=>75$ to $100 \%$ root rot.
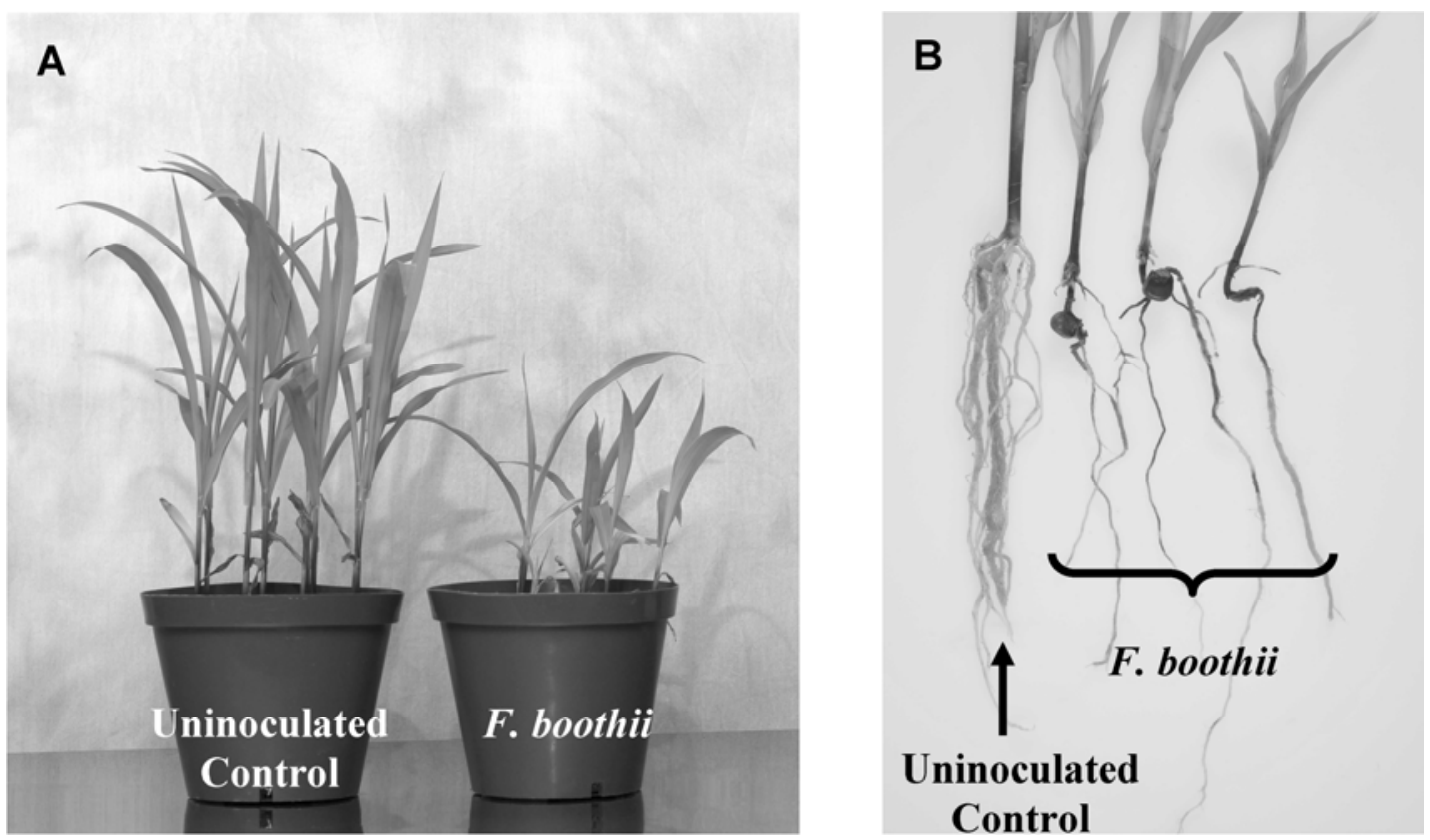

Fig. 2. Maize seedlings grown in soil artificially infested with Fusarium boothii isolate PPRI 10703 in a glasshouse. A, Reduction in survival and growth caused by the fungus. B, Root rot caused by the fungus. 
plant growth (Table 3), although not always in both trials (however, for individual isolates, data not shown).

\section{Discussion}

The phylogenetic analysis using the Tril01 gene region sequences revealed the presence of three species within the $F$. graminearum species complex from maize crowns and roots in South Africa. Although $F$. boothii was previously recorded from maize grain locally (22), this is the first report of $F$. graminearum sensu stricto, $F$. meridionale, and $F$. boothii to be identified on diseased maize crowns and roots in South Africa and, as far as we can determine, in the world.

Isolates used in this study were obtained from no-till maize grown mostly in a double cropping system with wheat. Previous studies showed that $F$. graminearum sensu stricto (= lineage 7 ) $(22,24)$ is the predominant species in the $F$. graminearum species complex associated with wheat scab worldwide. Of the 33 isolates molecularly characterized in our study, 26 were identified as $F$. graminearum sensu stricto (= lineage 7 ) and, because wheat was the predominant rotation crop grown with the maize from which the isolates were obtained, it is possible that wheat is an important source of $F$. graminearum sensu stricto inoculum for infection of maize crowns and roots.
The pathogenicity results showed that $F$. boothii was the most and $F$. meridionale the least virulent of the three Fusarium spp. tested on maize seedlings in this study. Unfortunately, only two isolates of $F$. boothii and five isolates of $F$. meridionale were available for pathogenicity tests. Although many reports are available on the pathogenicity of $F$. graminearum species complex on maize roots $(2,7,18-20)$, this is the first report on the ability of species in the $F$. graminearum species complex to cause soilborne diseases of maize, and also the first comprehensive study on Fusarium spp. in the $F$. graminearum species complex as soilborne pathogens of maize in South Africa.

The chemotypes of the isolates used in this study were not determined. Other researchers found a close relationship between the severity of diseases caused by $F$. graminearum species complex isolates and the concentration of deoxynivalenol (DON) produced in infected seedling tissue (2). Isolates of $F$. boothii and $F$. meridionale obtained from cereal grains and studied in Argentina belonged to the nivalenol (NIV) chemotype and $F$. graminearum sensu stricto to the DON chemotype (26). In Brazil, isolates representing the DON or 15-ADON genotype were $F$. graminearum sensu stricto and the isolates representing the NIV genotype were $F$. meridionale (29).

Pathogenicity tests on maize roots with soilborne fungi were previously conducted by other researchers using a 1, 2, and $3 \%$

Table 3. Analysis of variance for the effect of Fusarium boothii, F. graminearum sensu stricto, and F. meridionale on survival and growth of maize seedlings

\begin{tabular}{|c|c|c|c|c|c|c|}
\hline \multirow[b]{2}{*}{ Source } & \multicolumn{3}{|c|}{ Trial 1} & \multicolumn{3}{|c|}{ Trial 2} \\
\hline & df & MS & $P$ value & df & MS & $P$ value \\
\hline \multicolumn{7}{|l|}{ Survival } \\
\hline Rep & 2 & $1,070.59$ & 0.0166 & 2 & 943.17 & 0.0173 \\
\hline Isolates plus control & 33 & $1,378.76$ & $<0.0001$ & 33 & $2,242.76$ & $<0.0001$ \\
\hline Between species and control & 3 & $3,659.84$ & $<0.0001$ & 3 & $5,060.67$ & $<0.0001$ \\
\hline Isolates within $F$. boothii & 1 & 16.67 & 0.7952 & 1 & 66.67 & 0.5826 \\
\hline Isolates within $F$. graminearum & 25 & $1,367.85$ & $<0.0001$ & 25 & $2,283.49$ & $<0.0001$ \\
\hline Isolates within $F$. meridionale & 4 & 76.67 & 0.8688 & 4 & 417.97 & 0.1188 \\
\hline Error & 66 & 245.34 & $\ldots$ & 66 & 218.61 & $\ldots$ \\
\hline Corrected total & 101 & $\ldots$ & $\ldots$ & 101 & $\ldots$ & $\ldots$ \\
\hline \multicolumn{7}{|l|}{ Growth (shoot length) } \\
\hline Rep & 2 & $9,678.45$ & 0.0978 & 2 & $96,282.83$ & $<0.0002$ \\
\hline Isolates plus control & 33 & $61,609.66$ & $<0.0001$ & 33 & $116,655.96$ & $<0.0001$ \\
\hline Between species and control & 3 & $132,817.34$ & $<0.0001$ & 3 & $176,413.29$ & $<0.0001$ \\
\hline Isolates within $F$. boothii & 1 & $22,962.59$ & 0.0197 & 1 & $37,187.52$ & 0.0550 \\
\hline Isolates within $F$. graminearum & 25 & $56,346.73$ & $<0.0001$ & 25 & $118,651.16$ & $<0.0001$ \\
\hline Isolates within $F$. meridionale & 4 & $51,818.41$ & $<0.0001$ & 4 & $77,749.92$ & $<0.0001$ \\
\hline Error & 66 & $4,018.54$ & $\ldots$ & $64(2)$ & $9,746.09$ & $\ldots$ \\
\hline Sample error & 646 & 2,315.07 & $\ldots$ & 592 & $5,183.93$ & $\ldots$ \\
\hline Corrected total & 747 & ... & $\ldots$ & 691 & $\ldots$ & $\cdots$ \\
\hline
\end{tabular}

Table 4. Analysis of variance for the effect of Fusarium boothii, F. graminearum sensu stricto, and F. meridionale on root rot severity and crown rot of maize seedlings

\begin{tabular}{|c|c|c|c|c|c|c|}
\hline \multirow[b]{2}{*}{ Source } & \multicolumn{3}{|c|}{ Trial 1} & \multicolumn{3}{|c|}{ Trial 2} \\
\hline & df & MS & $P$ value & df & MS & $P$ value \\
\hline \multicolumn{7}{|l|}{ Root rot severity } \\
\hline Rep & 2 & 0.33 & 0.5826 & 2 & 0.11 & 0.8747 \\
\hline Isolates plus control & 33 & 25.36 & $<0.0001$ & 30 & 16.33 & $<0.0001$ \\
\hline Between species and control & 3 & 89.44 & $<0.0001$ & 3 & 29.41 & $<0.0001$ \\
\hline Isolates within $F$. boothii & 1 & 0.00037 & 0.9805 & 1 & 20.83 & $<0.0001$ \\
\hline Isolates within $F$. graminearum & 25 & 19.21 & $<0.0001$ & 25 & 17.2 & $<0.0001$ \\
\hline Isolates within $F$. meridionale & 4 & 22.11 & $<0.0001$ & 4 & 0.25 & 0.8633 \\
\hline Error & 66 & 0.61 & $\ldots$ & $64(2)$ & 0.78 & $\ldots$ \\
\hline Sample error & 641 & 0.26 & $\ldots$ & 601 & 0.11 & $\ldots$ \\
\hline Corrected total & 742 & $\ldots$ & $\ldots$ & 700 & $\ldots$ & $\ldots$ \\
\hline \multicolumn{7}{|l|}{ Percent seedlings with crown rot } \\
\hline Rep & 2 & 414.39 & 0.1756 & 2 & 85.92 & 0.6571 \\
\hline Isolates plus control & 33 & $2,972.69$ & $<0.0001$ & 33 & $3,424.35$ & $<0.0001$ \\
\hline Between species and control & 3 & $6,306.18$ & $<0.0001$ & 3 & $6,453.92$ & $<0.0001$ \\
\hline Isolates within $F$. boothii & 1 & 13.29 & 0.8116 & 1 & 46.3 & 0.6347 \\
\hline Isolates within $F$. graminearum & 25 & $2,448.37$ & $<0.0001$ & 25 & $3,384.27$ & $<0.0001$ \\
\hline Isolates within $F$. meridionale & 4 & $4,489.41$ & $<0.0001$ & 4 & $2,313.33$ & $<0.0001$ \\
\hline Error & 66 & 232.01 & $\ldots$ & $64(2)$ & 203.25 & $\ldots$ \\
\hline Corrected total & 101 & $\ldots$ & $\ldots$ & 99 & $\ldots$ & $\ldots$ \\
\hline
\end{tabular}


(wt/wt, mass inoculum/mass growth medium) inoculum level $(3,6,12)$. Despite the low inoculum concentration $(0.5 \%$, wt/wt $)$ used in this study, the Fusarium spp. caused significant crown and root rot on maize seedlings and we were able to differentiate between the virulence of the three species. According to our results, $F$. graminearum sensu stricto and $F$. boothii are important soilborne pathogens of maize. This is supported by field data where a significant positive correlation was reported between the incidence of $F$. graminearum species complex and crown and root rot severity of maize in KwaZulu-Natal, especially at the end of the season (14).

\section{Acknowledgments}

We thank the Maize Trust and Agricultural Research Council for financial support of the project; M. P. W. Farina and G. Thibaud for conducting the field trials where maize plants were sampled for isolation of $F$. graminearum species complex; A. Schoeman, A. Van den Heever, T. Phasoana, S. Williams, G. Anthony, and J. Deysel for technical assistance; and W. F. O. Marasas for critical reading and editing of the manuscript.

\section{Literature Cited}

1. Andrés Ares, J. L., Alonso Ferro, R. C., Campo Ramírez, L., and Moreno González, J. 2004. Fusarium graminearum Schwabe, a maize root and stalk rot pathogen isolated from lodged plants in northeastern Spain. Span. J. Agric. Res. 2:249-252.

2. Asran, M. R., and Buchenauer, H. 2003. Pathogenicity of Fusarium graminearum isolates on maize (Zea mays $\mathrm{L}$.) cultivars and relation with deoxynivalenol and ergosterol contents. Z. Pflanzenkrankh. Pflanzenschutz 110:209-219.

3. Chambers, K. R. 1987. Ability of fungal isolates from maize and sorghum to infect roots and reduce seedling emergence of two maize hybrids. Plant Dis. 71:736-739.

4. Chambers, K. R. 1987. Epidemiology of maize root rot in South Africa. J. Phytopathol. 118:84-93.

5. Daniels, B. A. 1983. Elimination of Fusarium moniliforme from corn seed. Plant Dis. 67:609-611.

6. Deacon, J. W., and Scott, D. B. 1983. Phialophora zeicola sp. nov., and its role in the root rot-stalk rot complex of maize. Trans. Br. Mycol. Soc. $81: 247-262$.

7. Du Toit, L. J., Kirby, H. W., and Pedersen, W. L. 1997. Evaluation of an aeroponics system to screen maize genotypes for resistance to Fusarium graminearum seedling blight. Plant Dis. 81:175-179.

8. Harrison, C. J., and Langdale, J. A. 2006. A step by step guide to phylogeny reconstruction. Plant J. 45:561-572.

9. Hornby, D., and Ullstrup, A. J. 1967. Fungal populations associated with maize roots. Composition and comparison of mycofloras from genotypes differing in root rot resistance. Phytopathology 57:869-875.

10. Katoh, K., and Toh, H. 2008. Recent developments in the MAFFT multiple sequence alignment program. Bioinformatics 9:286-298.

11. Kimura, M., Kaneko, I., Komiyama, M., Takatsuki, A., Koshino, H., Yoneyama, H., and Yamaguchi, I., 1998. Trichothecene 3-O-acetyltransferase protects both the producing organism and transformed yeast from related mycotoxins. Cloning and characterization of Tri101. J. Biol. Chem. 273:1654-1661.

12. Krüger, W., and Rogdaki-Papadaki, C. 1980. On the effect of temperature, soil type, soil compression and fertilization on root rot and the fungus spectrum of maize. Z. Pflanzenkrankh. Pflanzenschutz 87:298-316.

13. Lamprecht, S. C. 1986. A new disease of Medicago truncatula caused by Cylindrocladium scoparium. Phytophylactica 16:189-193.

14. Lamprecht, S. C., Farina, M. P. W., Thibaud, G. R., Marais, M., Habig, J. H., Bloem, J. F., and Swart, A. 2008. Fusarium graminearum on maize crowns and roots in South Africa. J. Plant Pathol. 90:S3.73.

15. Lee, S. B., and Taylor, J. W. 1990. Isolation of DNA from fungal mycelia and single spores. Pages 282-287 in: PCR Protocols: A Guide to Methods and Applications. M. A. Innis, D. H. Gelfand, J. J. Sninsky, and T. J. White, eds. Academic Press, San Diego, CA.
16. Marasas, W. F. O., Nelson, P. E., and Toussoun, T. A. 1984. Toxigenic Fusarium species: Identity and Mycotoxicology. The Pennsylvania State University Press, University Park.

17. Marasas, W. F. O., Voigt, W. G. J., Lamprecht, S. C., and Van Wyk, P. S. 1988. Crown rot and head blight of wheat caused by Fusarium graminearum groups 1 and 2 in the Southern Cape Province. Phytophylactica 20:385-389.

18. Miller, R. E. 1963. A root rot complex of field maize: Symptomatology, sequence of fungi involved and the effect of corn root exudate on these fungi. Ph.D. thesis. Cornell University. Diss. Abstr. 24:3921.

19. Moreno-González, J., Andrés Ares, J. L., Alonso Ferro, R., and Campo Ramírez, L. 2004. Genetic and statistical models for estimating parameters of maize seedling resistance to Fusarium graminearum Schwabe root rot. Euphytica 137:55-61.

20. Munkvold, G. P., and O'Mara, J. K. 2002. Laboratory and growth chamber evaluation of fungicidal seed treatments for maize seedling blight caused by Fusarium species. Plant Dis. 86:143-150.

21. Nelson, P. E., Toussoun, T. A., and Marasas, W. F. O. 1983. Fusarium species. An Illustrated Manual for Identification. The Pennsylvania State University Press, University Park.

22. O'Donnell, K., Kistler, H. C., Tacke, B. K., and Casper, H. H. 2000. Gene genealogies reveal global phylogeographic structure and reproductive isolation among lineages of Fusarium graminearum, the fungus causing wheat scab. Proc. Natl. Acad. Sci. USA 97:7905-7910.

23. O'Donnell, K., Ward, T. J., Aberra, D., Kistler, H. C., Aoki, T., Orwig, N., Kimura, M., Bjørnstad, Å., and Klemsdal, S. S. 2008. Multilocus genotyping and molecular phylogenetics resolve a novel head blight pathogen within the Fusarium graminearum species complex from Ethiopia. Fungal Genet. Biol. 45:1514-1522.

24. O'Donnell, K., Ward, T. J., Geiser, D. M., Kistler, H. C., and Aoki, T. 2004 Genealogical concordance between mating type locus and seven nuclear genes supports formal recognition of nine phylogenetically distinct species within the Fusarium graminearum clade. Fungal Genet. Biol. 41:600-623.

25. Ramsey, M. D. 1990. Etiology of root and stalk rots of maize in North Queensland. Disease development and associated fungi. Australas. Plant Pathol. 19:2-12

26. Sampietro, D. A., Marin, P., Iglesias, J., Presello, D. A., Vattuone, M. A., Catalan, C. A. N., and Gonzalez Jaen, M. T. 2010. A molecular based strategy for rapid diagnosis of toxigenic Fusarium species associated to cereal grains from Argentina. Fungal Biol. 114:74-81.

27. Santiago, R., Reid, L. M., Zhu, X., Butrón, A., and Malvar, R.A. 2010 Gibberella stalk rot (Fusarium graminearum) resistance of maize inbreds and their $\mathrm{F}_{1}$ hybrids and their potential for use in resistance breeding programs. Plant Breed. 129:454-456.

28. Schaafsma, A. W., Tamburic-Ilincic, L., and Hooker, D. C. 2005. Effect of previous crop, tillage, field size, adjacent crop, and sampling direction on airborne propagules of Gibberella zeae/Fusarium graminearum head blight severity, and deoxynivalenol accumulation in winter wheat. Can. J. Plant Pathol. 27:217-224.

29. Scoz, L. B., Astolfi, P., Reartes, D. S., Schmale, D. G., III, Moraes, M. G., and del Ponte, E. M. 2009. Trichothecene mycotoxin genotypes of Fusarium graminearum sensu stricto and $F$. meridionale in wheat from southern Brazil. Plant Pathol. 58:344-351.

30. Shapiro, S. S., and Wilk, M. B. 1965. An analysis of variance for normality (complete samples). Biometrika 52:591-611.

31. Starkey, D. E., Ward, T. J., Aoki, T., Gale, L. R., Kistler, H. C., Geiser, D. M., Suga, H., Tóth, B., Varga, J., and O’Donnell, K. 2007. Global molecular surveillance reveals novel Fusarium head blight species and trichothecene toxin diversity. Fungal Genet. Biol. 44:1191-1204.

32. Swofford, D. L. 2002. PAUP 4.0b10: Phylogenetic Analysis Using Parsimony. Sinauer Associates, Inc., Publishers, Sunderland, MA.

33. White, D. G. 1999. Compendium of Corn Diseases, 3rd ed. American Phytopathological Society, St. Paul, MN.

34. Yli-Mattila, T., Gagkaeva, T., Ward, T. J., Aoki, T., Kistler, H. C., and O'Donnell, K. 2009. A novel Asian clade within the Fusarium graminearum species complex includes a newly discovered cereal head blight pathogen from the Far East of Russia. Mycologia 101:841-852. 